\title{
Parasite fauna of Golden Grey Mullet Liza aurata (Risso, 1810) collected from Lower Kızılırmak Delta in Samsun, Turkey
}

\author{
A. ÖZER ${ }^{1}$, D. Y. KIRCA ${ }^{1}$ \\ ${ }^{1}$ Sinop University, Faculty of Fisheries and Aquatic Sciences, 57000 Sinop, Turkey, E-mail:aozer@sinop.edu.tr
}

\begin{abstract}
Summary
The mugilids are among the most cosmopolitan teleost fishes and they are widely distributed in fresh, brackish and coastal marine waters of the tropical and temperate regions of the world. Liza aurata is one of eight mugilid species survive in Turkish waters. Parasite fauna of the golden grey mullet Liza aurata (Risso, 1810) collected from Lower Kizllırmak Delta in Samsun, Turkey were investigated in the present study. Standard parasitological investigation methods were applied and standard indices of infection were calculated. A total of 10 parasite species were identified and they are; Trichodina puytoraci, Trichodina lepsii, Ligophorus mediterraneus, Ligophorus cephali, Microcotyle mugilis, Ascocotyle (Phagicola) longa, Haplosplanchnus pachysomus, Tylodelphys clavata, Neoechinorhyncus agilis and Ergasilus lizae. Overall infection prevalence was $100 \%$ and both the mean intensity and abundance values were $190.09 \pm 43.15$ parasites per infected/examined fish. Ligophorus-group parasites were the most abundant $(97.83 \%)$ and Tylodelphys clavata was the least $(4.35 \%)$ among all parasite species identified. Water temperature $(\mathrm{C})$, dissolved oxygen $(\mathrm{mg} / \mathrm{lt})$, salinity (ppt) and nitrate $(\mathrm{mg} / \mathrm{lt})$ values were also presented. According to results obtained in the present study, Ligophorus cephali, Ligophorus mediterraneus, Thylodelphys clavata and Ascocotyle (Phagicola) longa are new parasite records for L. aurata and Ligophorus mediterraneus, Ligophorus cephali and Ergasilus lizae are the new parasite records for Turkish parasite fauna of fish in Turkey.
\end{abstract}

Keywords: Liza aurata; parasite fauna; Kız1lırmak delta; Turkey

\section{Introduction}

The mugilids are among the most cosmopolitan teleost fishes and they are widely distributed in fresh waters, brackish waters and coastal marine waters of the tropical and temperate regions of the world. They are known to be euryhaline fishes and are prevalent in coastal lagoons due to their high mobility and tolerance to environmental conditions such as temperature and salinity. The family Mugilidae includes 17 genera and $>75$ species in the world (Nelson, 2006). Mugilid species are commonly found along the Mediterranean and Black Seas and represented with four genera and nine species. In Turkish waters, there are eight species of Mugilidae and they are; Mugil cephalus L., 1758, Liza aurata (Risso, 1810), Liza ramada (Risso, 1827), Liza saliens (Risso, 1810), Liza abu (Heckel, 1843), Oedalachilus labeo (Cuvier, 1829), Chelon labrosus (Risso, 1827) and Liza haematocheila (Temminck \& Schlegel, 1845). Of these, golden grey mullet $L$. aurata is found in the Black Sea region of Turkey. There have been several published studies on the parasite fauna of this fish species (see Table 1 for detailed list). Dmitrieva et al. (2012) also provided updated information on Ligophorus species which are all specific to mugilids. However, research studies on the parasite fauna and parasite ecology of golden grey mullet are very rare and still incomplete. The objective of this investigation was to study the natural parasite fauna of Liza aurata from Kızılırmak Delta, an area of ecologically important and protected by the law, in Samsun, Turkey and to extend our knowledge about its parasite fauna, infection levels and distribution of its parasite species.

\section{Materials and Methods}

Kizilirmak Delta is one of the biggest wetlands in Turkey with the largest bird diversity of 322 and 25 fish species. It is located in the border of Samsun city $\left(41^{\circ} 38^{\prime} 38.84^{\prime \prime} \mathrm{N}\right.$ and $36^{\circ} 04^{\prime} 09.89^{\prime \prime} \mathrm{E}$ ) and lies at the sea level. Parasitological investigation was conducted in the lagoon lakes of Karaboğaz (170 ha) and Liman (272 ha) (Fig. 1). These lagoons have direct connection with the Black Sea time to 
Table 1. Parasite species reported from golden grey mullet from different locations by different authors

\begin{tabular}{|c|c|c|}
\hline Parasite species & Location & Authors \\
\hline Trichodina puytoraci & Sinop, Turkey & Özer \& Öztürk (2004) \\
\hline “ & Azov and Black Sea & Dmitrieva \& Gaevskaya (2001) \\
\hline Trichodina lepsii & Sinop, Turkey & Özer \& Öztürk (2004) \\
\hline “ & Azov and Black Sea & Dmitrieva \& Gaevskaya (2001) \\
\hline “ & Ghar El Mehl LagoonTunisia & Yemmen et al. (2012) \\
\hline Ligophorus szidati & Mitras Lagoon, Sardinia & Merella \& Garippa (2001) \\
\hline “ & Mediterranean Sea & $\begin{array}{l}\text { Mariniello et al. (2004) } \\
\text { ve ark., (2004)ve ark., (2004) }\end{array}$ \\
\hline “ & Azov and Black Sea & Sarabeev \& Balbuena (2004) \\
\hline “ & Azov and Black Sea & Dmitrieva \& Gaevskaya (2001) \\
\hline “ & Azov and Black Sea & Dmitrieva et al. (2012) \\
\hline “ & Black Sea & Gaevskaya \& Dmitrieva (1997) \\
\hline Ligophorus vanbenedenii & Mitras Lagoon, Sardinia & Merella \& Garippa (2001) \\
\hline “ & Mediterranean Sea & Mariniello et al. (2004) \\
\hline “ & Azov and Black Sea & Sarabeev \& Balbuena (2004) \\
\hline “ & Azov and Black Sea & Dmitrieva \& Gaevskaya (2001) \\
\hline “ & Azov and Black Sea & Dmitrieva et al. (2012) \\
\hline “ & Black Sea & Gaevskaya \& Dmitrieva (1997) \\
\hline Ligophorus kaohsianghsieni & Azov and Black Sea & Dmitrieva \& Gaevskaya (2000) \\
\hline “ & Azov and Black Sea & Dmitrieva et al. (2012) \\
\hline “ & Black Sea & Gaevskaya \& Dmitrieva (1997) \\
\hline Ligophorus macrocolpus & Azov and Black Sea & Dmitrieva \& Gaevskaya (2001) \\
\hline “ & Black Sea & Dmitrieva et al. (2012) \\
\hline “ & Black Sea & Gaevskaya \& Dmitrieva (1997) \\
\hline Ligophorus spp. & Greece & Ragias et al. (2005) \\
\hline Microcotyle mugilis & Azov and Black Sea & Dmitrieva \& Gaevskaya (2001) \\
\hline “ & Black Sea & Gaevskaya \& Dmitrieva (1997) \\
\hline Gyrodactylus alviga & Azov and Black Sea & Dmitrieva \& Gaevskaya (2001) \\
\hline Haplosplanchnus pachysomus & Azov and Black Sea & Dmitrieva \& Gaevskaya (2001) \\
\hline “ & Greece & Ragias et al. (2005) \\
\hline Saccocoelium obesum & Mitras Lagoon, Sardinia & Merella \& Garippa (2001) \\
\hline “ & Greece & Ragias et al. (2005) \\
\hline “ & Mediterranean Sea, Spain & Blasco-Costa et al. (2009) \\
\hline Saccocoelium tensum & Mitras Lagoon, Sardinia & Merella \& Garippa (2001) \\
\hline “ & Greece & Ragias et al, (2005) \\
\hline " & Mediterranean Sea, Spain & Blasco-Costa et al. (2009) \\
\hline Saturnius sp. & Mitras Lagoon, Sardinia & Merella \& Garippa (2001) \\
\hline Saturnius papernai & Mediterranean Sea, Spain & Blasco-Costa et al. (2009) \\
\hline “ & Azov and Black Sea & Dmitrieva \& Gaevskaya (2001) \\
\hline Saturnius mugili & Azov and Black Sea & Dmitrieva \& Gaevskaya (2001) \\
\hline Haploporus benedeni & Greece & Ragias et al. (2005) \\
\hline Dicrogaster contractus & Mitras Lagoon, Sardinia & Merella \& Garippa (2001) \\
\hline “ & Greece & Ragias et al. (2005) \\
\hline
\end{tabular}




\begin{tabular}{|c|c|c|}
\hline Lecithaster confusus & Greece & Ragias et al. (2005) \\
\hline Lecithobotrys putrescen & Greece & Ragias et al. (2005) \\
\hline Acanthostomum imbriformis mtc & Azov and Black Sea & Dmitrieva \& Gaevskaya (2001) \\
\hline Aphanurus stossichi & Azov and Black Sea & Dmitrieva \& Gaevskaya (2001) \\
\hline Clinostomum piscidium mtc & Azov and Black Sea & Dmitrieva \& Gaevskaya (2001) \\
\hline Dicrogaster contracta & Azov and Black Sea & Dmitrieva \& Gaevskaya (2001) \\
\hline Haploporus lateralis & Azov and Black Sea & Dmitrieva \& Gaevskaya (2001) \\
\hline Lecithaster galeata & Azov and Black Sea & Dmitrieva \& Gaevskaya (2001) \\
\hline Phagicola sinaceum mtc. & Azov and Black Sea & Dmitrieva \& Gaevskaya (2001) \\
\hline Wlassenkotrema longicolum & Azov and Black Sea & Dmitrieva \& Gaevskaya (2001) \\
\hline Capillaria sp. & Mitras Lagoon, Sardinia & Merella \& Garippa (2001) \\
\hline Contracaecum sp. & Mitras Lagoon, Sardinia & Merella \& Garippa (2001) \\
\hline Philometra taurica & Azov and Black Sea & Dmitrieva \& Gaevskaya (2001) \\
\hline Scolex pleoronectis & Azov and Black Sea & Dmitrieva \& Gaevskaya (2001) \\
\hline Neoechinorhyncus agilis & Mitras Lagoon, Sardinia & Merella and Garippa (2001) \\
\hline “ & Azov and Black Sea & Dmitrieva \& Gaevskaya (2001) \\
\hline “ & Greece & Ragias et al. (2005) \\
\hline Ergasilus lizae & Tunisia & Ben Hassein \& Raibaut (1981) \\
\hline Ergasilus nanus & Azov and Black Sea & Dmitrieva \& Gaevskaya (2001) \\
\hline Acanthogyrus lizae & Greece & Ragias et al. (2005) \\
\hline Caligus pageti & Mitras Lagoon, Sardinia & Merella \& Garippa (2001) \\
\hline Nerocila orbignyi & Mitras Lagoon, Sardinia & Merella \&Garippa (2001) \\
\hline “ & Greece & Ragias et al. (2005) \\
\hline Myxobolus exiguus & Azov and Black Sea & Dmitrieva \& Gaevskaya (2001) \\
\hline Myxobolus mugilis & Azov and Black Sea & Dmitrieva \& Gaevskaya (2001) \\
\hline “ & Mediterranean Sea & Perugia (1891) \\
\hline Myxobolus mulleri & Azov and Black Sea & Dmitrieva \& Gaevskaya (2001) \\
\hline Myxobolus parvus & Azov and Black Sea & Dmitrieva \& Gaevskaya (2001) \\
\hline Myxobolus branchiale & Azov and Black Sea & Dmitrieva \& Gaevskaya (2001) \\
\hline Pseudalataspora pontica & Black Sea & Dmitrieva \& Gaevskaya (2001) \\
\hline Sphaeromyxa sabrazesi & Black and Mediterranean Sea & Dmitrieva \& Gaevskaya (2001) \\
\hline “ & Black Sea & Ovcharenko \& Yurakhno (2008) \\
\hline Zschokkela dogieli & Black Sea & Dmitrieva \& Gaevskaya (2001) \\
\hline Zschokkela nova & Black Sea & Dmitrieva \& Gaevskaya (2001) \\
\hline Zschokkella admiranda & Black and Mediterranean Sea & Ovcharenko \& Yurakhno (2008) \\
\hline Ortholinea divergens & Black Sea & Yurakhno (1993) \\
\hline Sphaerospora dicentrarchi & Azov and Black Sea & Ovcharenko \& Yurakhno (2008) \\
\hline Polysporoplasma mugilis & Black and Mediterranean Sea & Sitja-Bobadilla \& Alvarez-Pellitero (1995) \\
\hline Chloromyxum kotorensis & Adriatic Sea & Lubat et al. (1989) \\
\hline Myxobolus mugauratus & Black Sea & Pogoroltseva (1964) \\
\hline Myxobolus rotundus & Black Sea & Chernova (1967) \\
\hline Kudoa trifolia & Mediterranean Sea & Holzer et al. (2006) \\
\hline Kudoa unicapsula & Mediterranean Sea & Yurakhno et al. (2007) \\
\hline
\end{tabular}

time over a year period. These lagoons have a water column of maximum depth $3 \mathrm{~m}$, with the average $1.5 \mathrm{~m}$.

In the present study, the parasite fauna of golden grey mullet, Liza aurata (Risso, 1810), was determined from 46 fish specimens caught by electroshock device or cast-net. Parasitological investigation was conducted at the Faculty of Fisheries and Aquatic Sciences in Sinop. All fish were weighed and measured and their sex was determined. Fish 


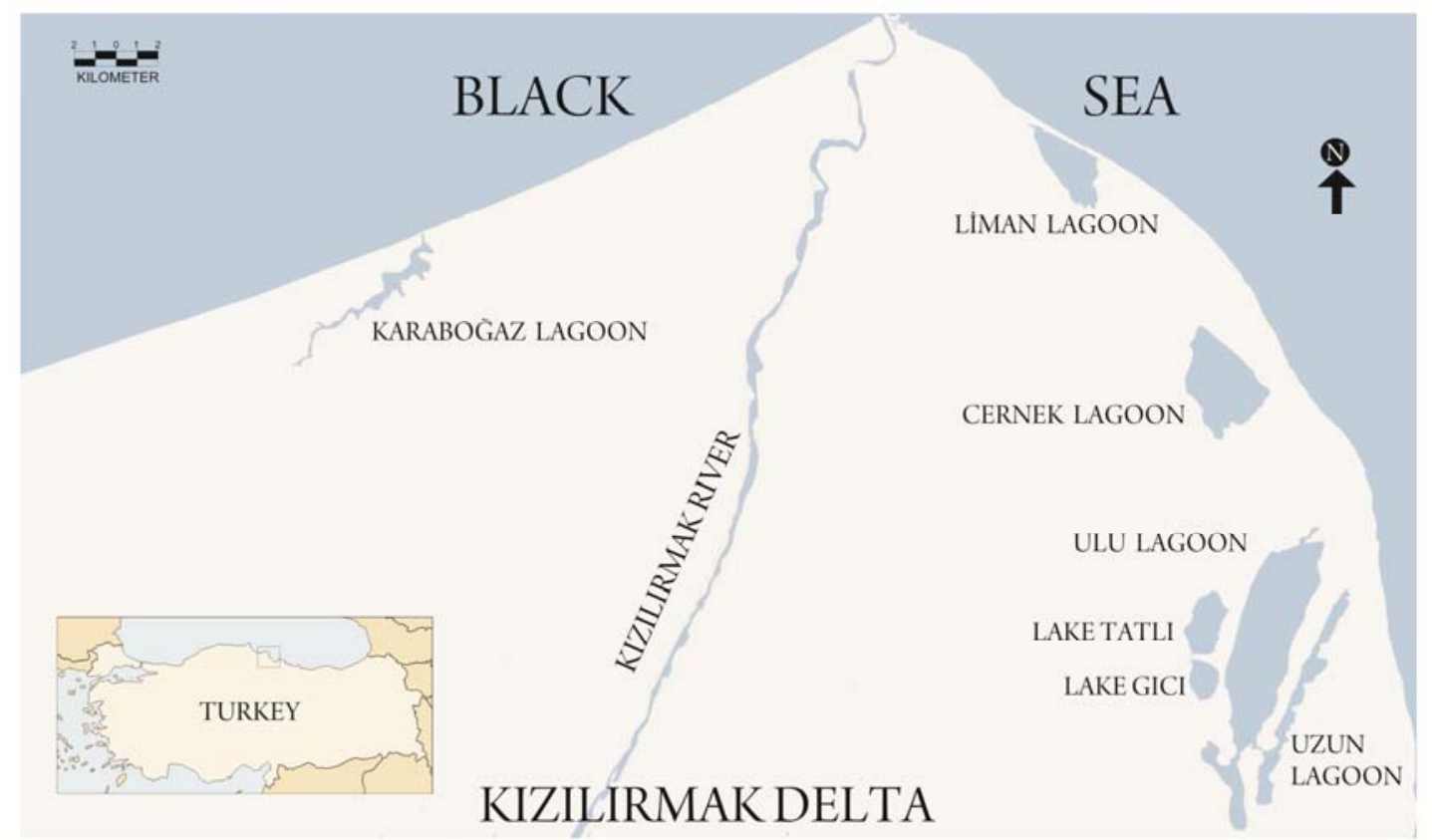

Fig. 1. Sampling sites of Karaboğaz and Liman Lagoons in Kızılırmak Delta

were subsequently examined for ecto- and endoparasites under a dissecting microscope. The examination included the skin, fins, gills, eyes (lens and vitreous humour), body cavity and visceral organs (stomach, intestine, liver, swimbladder, hearth and gonads). Parasites recovered were fixed and preserved using methods commonly applied. For SEM imaging, worms were dehydrated in a graded ethanol series, placed in hexamethyldisilazane and allowed to dry. They were mounted on stubs and coated with gold and then SEM micrographs were taken using a Jeol JSM-
6510LV scanning electron microscope at an accelerating voltage of $10 \mathrm{kV}$.

Infection prevalence (\%) and mean intensity follow the recommendations of Bush et al. (1997). The prevalence (\%) was calculated as the percentage of the total number of fish infected out of the total number of fish examined. The mean intensity was calculated as the average number of parasites in the total number of infected fish. The prevalence and mean intensity values of Trichodina ( $T$. puytoraci and T. lepsii) and Ligophorus species (L. cephali

Table 2. Parasite species identified and their overall infection prevalence (\%), mean intensity and abundance values in Kızılırmak Delta throughout the sampling period $(n: 46)$

\begin{tabular}{|c|c|c|c|c|}
\hline Parasite species & Microhabitat & $\begin{array}{l}\text { Prevalence } \\
\quad(\%)\end{array}$ & Mean Intensity \pm S.E. & Abundance \pm S.E \\
\hline \multicolumn{5}{|l|}{ Trichodina-group } \\
\hline $\begin{array}{l}\text { Trichodina puytoraci (Lom, 1962) } \\
\text { Trichodina lepsii (Lom, 1962) }\end{array}$ & $\begin{array}{l}\text { gills, skin } \\
\text { skin, gills }\end{array}$ & 56.52 & $81.11 \pm 36.56$ & $45.85 \pm 21.34$ \\
\hline $\begin{array}{l}\text { Ligophorus-group } \\
\text { Ligophorus cephali (Ruptsova et Euzet, 2006) } \\
\text { Ligophorus mediterraneus (Sarabeev, Balbuena, } \\
\text { Euzet, 2005) }\end{array}$ & $\begin{array}{l}\text { gills } \\
\text { gills }\end{array}$ & 97.83 & $88.93 \pm 17.41$ & $87.00 \pm 17.13$ \\
\hline Microcotyle mugilis (Vogt, 1878) & gills & 8.70 & $2.75 \pm 1.44$ & $0.24 \pm 0.16$ \\
\hline Ascocotyle (Phagicola) longa Ransom, 1920 & gills, hearth & 6.52 & $6.00 \pm 3.05$ & $0.39 \pm 0.27$ \\
\hline Tylodelphys clavata (Nordmann, 1832) & humour vitrous & 4.35 & $1.00 \pm 0.00$ & $0.04 \pm 0.03$ \\
\hline $\begin{array}{l}\text { Haplosplanchnus pachysomus (Eysenhardt, 1829) } \\
\text { Loss, 1902) }\end{array}$ & intestine & 39.13 & $128.72 \pm 37.77$ & $50.37 \pm 17.28$ \\
\hline Neoechinorhyncus agilis (Rudolphi, 1819) & intestine & 47.83 & $6.14 \pm 1.58$ & $2.93 \pm 0.87$ \\
\hline Ergasilus lizae (Krøyer, 1863) & gills & 50.00 & $6.87 \pm 1.72$ & $3.43 \pm 0.99$ \\
\hline Overall & & 100.00 & $190.09 \pm 43.15$ & $190.09 \pm 43.15$ \\
\hline
\end{tabular}




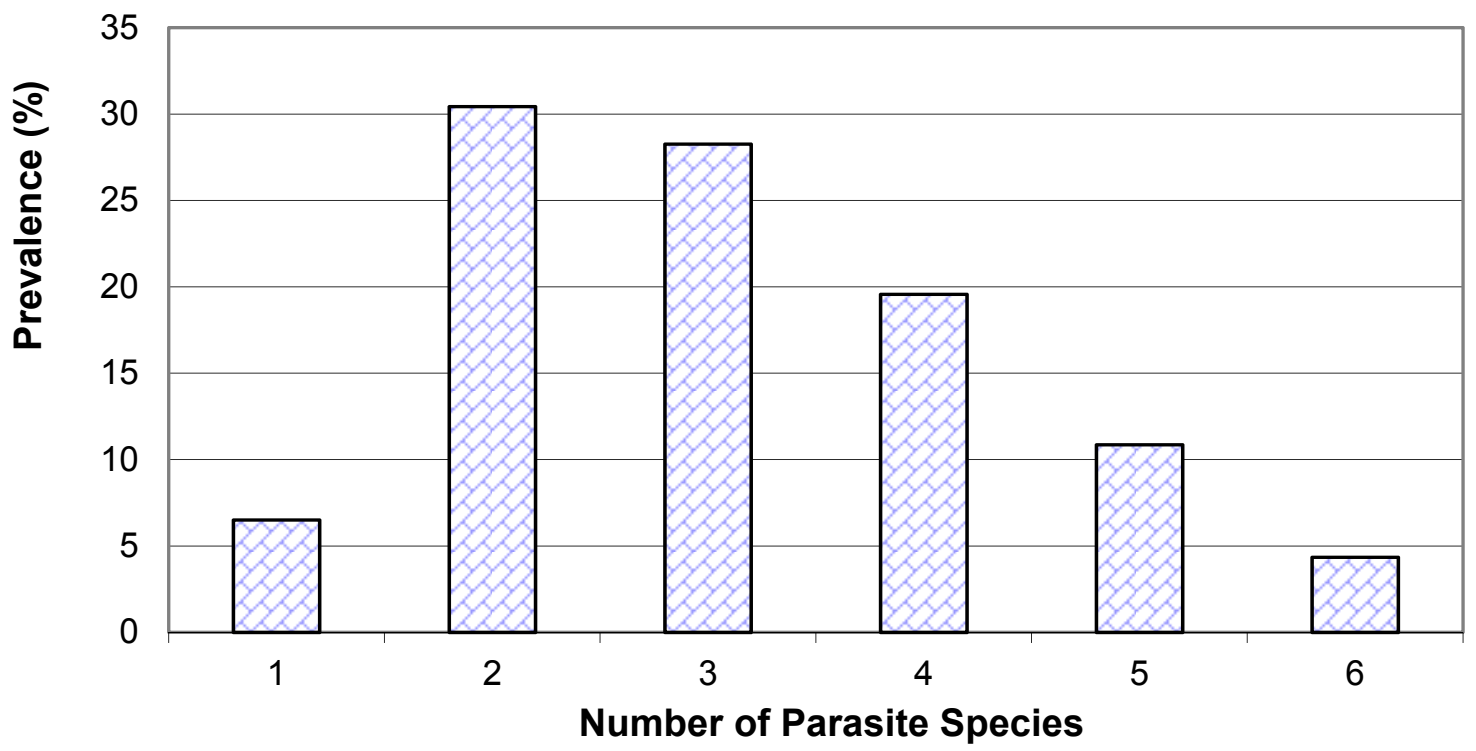

Fig. 2. Infection prevalences (\%) with respect to the number of parasite species detected in the golden grey mullet throughout the investigation period

and L. mediterraneus) were given for pooled data as group rather than by species.

Physico-chemical parameters (temperature (C), dissolved oxygen (mg/lt), salinity (ppt) and nitrate (ppt)) values were measured by YSI professional plus water quality instrument.

\section{Results}

The current study is the first to report on the parasite fauna of golden grey mullet captured from Lower Kizilırmak Delta in Turkey and among its kind in the world in terms of being a delta. A total of 10 parasite species was identified: 6 ectoparasites and 4 endoparasites (Table 2, Plate 1). If the number of parasite species in the individual host (infra community) is regarded, it is apparent that the majority of golden grey mullet hosts were infected with mostly by two and, secondly, by three parasite species (Fig. 2). It must be noted that, as was explained in M\&M section, Trichodina puytoraci and T. lepsii along with Ligophorus cephali and L. mediterraneus were designed as groups only. Trichodina puytoraci and Ligophorus cephali dominated over their counterparts in the fish specimens examined and there was a rate of $75: 1$ in favour of above mentioned species. Ectoparasitic species of Trichodina,
Ligophorus and Ergasilus were commonly found together parasitizing their hosts and only one or two digenean species contributed at the same time as the indication of parasite community numbers in Fig. 2.

Data on the parasite list with indications of infection prevalence, mean intensity and abundance values are presented in Table 2. Overall infection prevalence was $100 \%$, and both the mean intensity and abundance values were equal as $190.09 \pm 43.15$ parasites per infected/examined fish. The overall maximum infection prevalence was determined for Ligophorus-group (97.83\%), followed by Trichodina-group $(56.52 \%)$, E. lizae $(50 \%)$, N. agilis $(47.83 \%)$ and $H$. pachysomus $(39.13 \%)$ throughout the investigation period (Table 2). On the other hand, the overall maximum mean intensity value was for $H$. pachysomus (128.72 \pm 37.77$)$, followed by Ligophorus-group $(88.93 \pm 17.41)$ and Trichodina-group $(81.11 \pm 36.56)$ (Table 2). Microcotyle mugilis, Ascocotyle (Phagicola) longa and $T$. clavata were rare throughout this survey study.

Water parameters temperature $(\mathrm{C})$, dissolved oxygen $(\mathrm{mg} / \mathrm{lt})$, salinity (ppt) and nitrate (mg/lt) values were measured from Liman and Karaboğaz Lagoons were presented in Table 3.

Table 3. Water temperature $\left({ }^{\circ} \mathrm{C}\right)$, dissolved oxygen $(\mathrm{mg} / \mathrm{lt})$, salinity $(\mathrm{ppt})$ and nitrate $(\mathrm{mg} / \mathrm{lt})$ values measured from sampling sites according to seasons in sampled lagoons

\begin{tabular}{lcccccccc}
\hline Lagoon/Seasons & \multicolumn{4}{c}{ Spring (March-May) } & \multicolumn{4}{c}{ Autumn (September-October) } \\
& $\mathrm{T}$ & $\mathrm{DO}$ & $\mathrm{S}$ & $\mathrm{NO}_{3}$ & $\mathrm{~T}$ & $\mathrm{DO}$ & $\mathrm{S}$ & $\mathrm{NO}_{3}$ \\
\hline Liman Lagoon & 18.0 & 10.7 & 2.35 & 2.25 & 13.0 & 10.8 & 1.51 & 0.2 \\
& & & & & & & & \\
Karaboğaz Lagoon & 21.3 & 7.7 & 2.80 & 2.38 & 14.2 & 9.5 & 1.50 & 0.6 \\
\hline T - Temperature $\left({ }^{\circ} \mathrm{C}\right) ; \mathrm{DO}-$ Dissolved oxygen $(\mathrm{mg} / \mathrm{lt}) ; \mathrm{S}-$ Salinity $(\mathrm{ppt}) ; \mathrm{NO}_{3}-$ Nitrate $(\mathrm{mg} / \mathrm{lt})$ & &
\end{tabular}



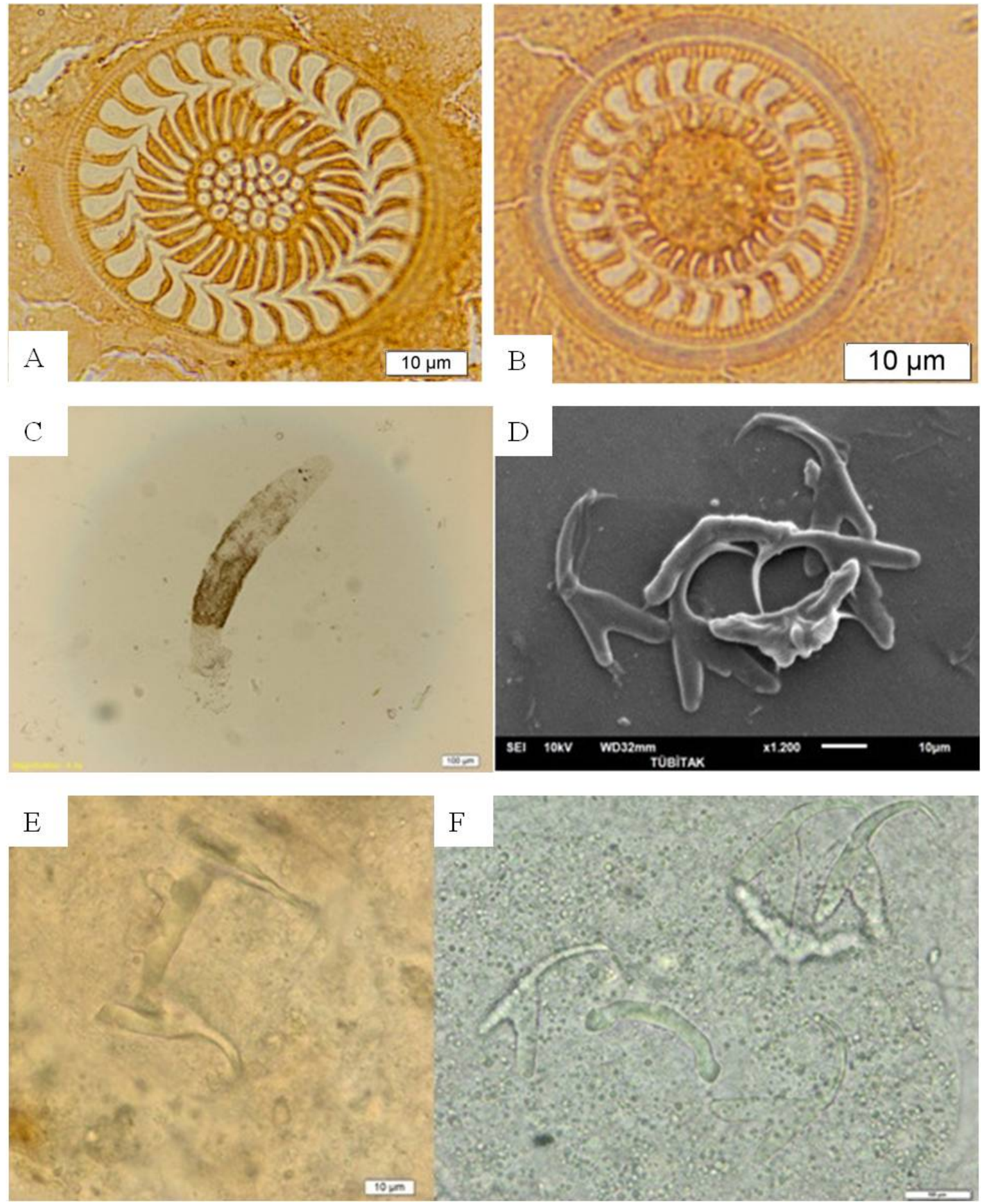

Plate I. Parasite species identified in Liza aurata. A - Trichodina puytoraci; B - Trichodina lepsii; C, D - Ligophorus cephali; E, F-Ligophorus mediterraneus; Scale bars: A, B, D, E- $10 \mu \mathrm{m} ; \mathrm{C}, \mathrm{F}-100 \mu \mathrm{m}$

\section{Discussion}

A wide variety of parasite species including two trichodinids, three monogeneans, three digenean trematodes, one acanthocephalan and one copepod species were identified in Liza aurata during the present study. The number of parasite species (10) identified here is similar to that reported by Merella and Garippa (2001) and Ragias et al.
(2005) but, far more than that of Dmitrieva and Gaevskaya (2001), Özer and Öztürk (2004), Mariniello et al. (2004), Sarabeev and Balbuena (2004), Blasco-Costa et al. (2006), Blasco-Costa et al. (2009) (see table 1). In the infra community level, most of the fish were found to be parasitized by 2 species as was dominated by Trichodina, Ligophorus and Ergasilus, all being ectoparasites on the gills of host fish. Ectoparasites are known to be affected heavily by 

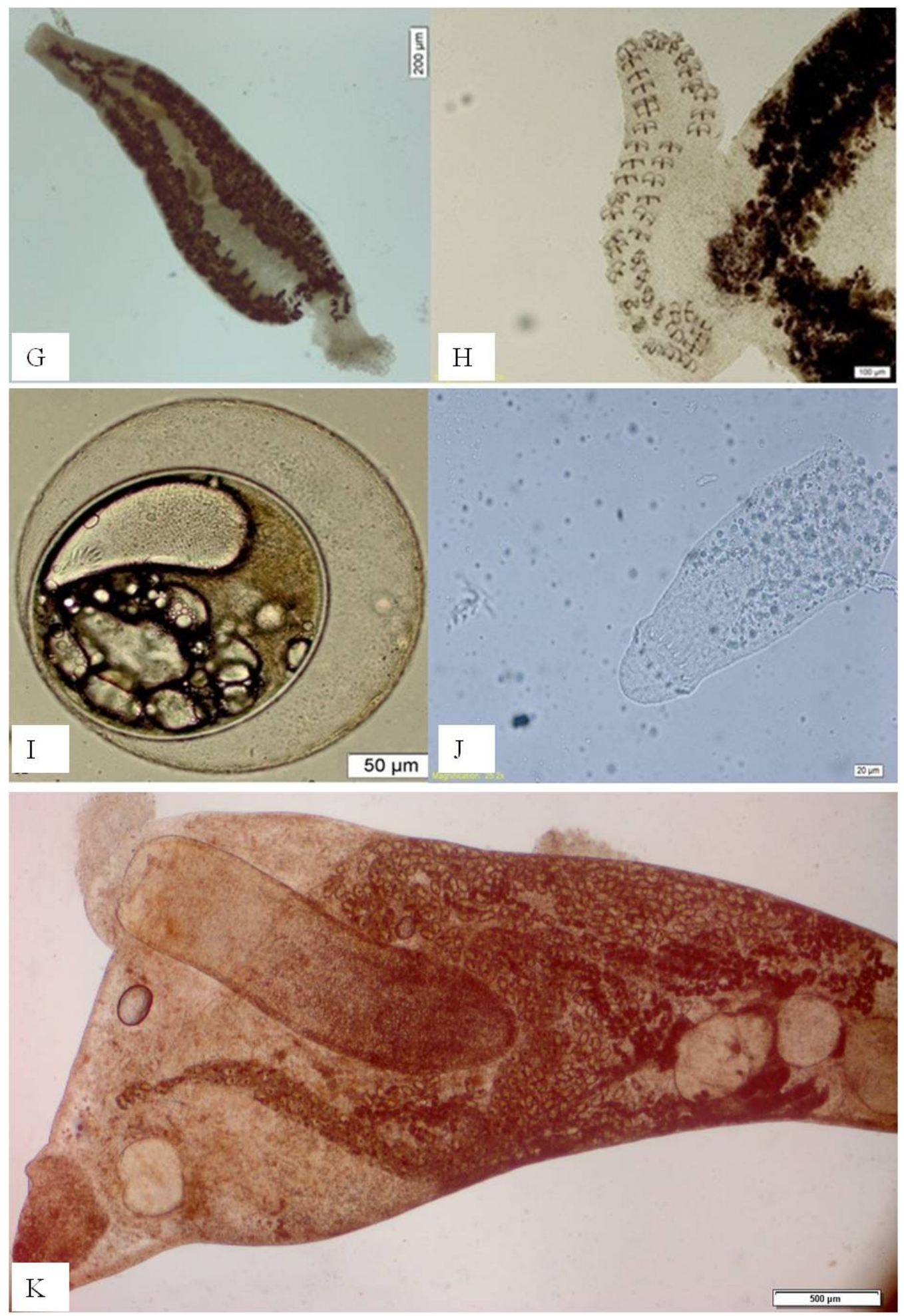

Plate I. - second part. G, H - Microcotyle mugilis; I, J - Ascocotyle (Phagicola) longa; K - Haplosplanchus pachysomus; Scale bars: $\mathrm{G}-200 \mu \mathrm{m} ; \mathrm{H}-100 \mu \mathrm{m} ; \mathrm{I}-50 \mu \mathrm{m} ; \mathrm{J}-20 \mu \mathrm{m} ; \mathrm{K}-500 \mu \mathrm{m}$

differing water conditions. On the other hand, digeneans and acanthocephalans need intermediate hosts to complete their life cycle and their infection process is fairly stable when compared to those of ectoparasites of fish.

Trichodinids are probably the most commonly encountered protozoan parasites on wild and cultured fishes in marine as well as freshwater environments (Urawa, 1992). Host specificity in trichodinids appears variable, Trichodina puytoraci and $T$. lepsii have been reported from mugilids including Liza aurata in different environment by several authors (see Table 1). Monogeneans are well-known typical external parasites of mugilid fishes. Because all mugi- 

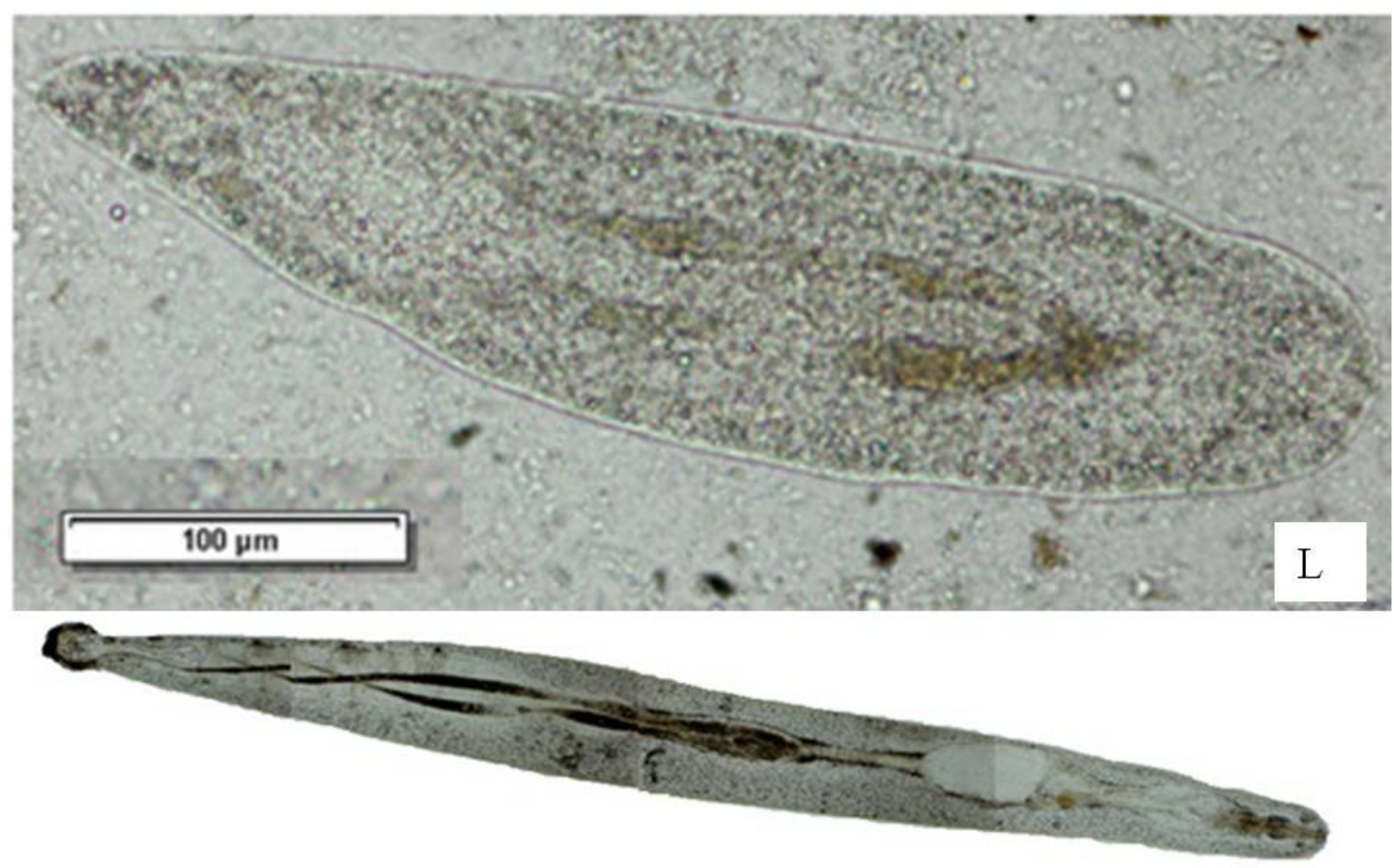

M

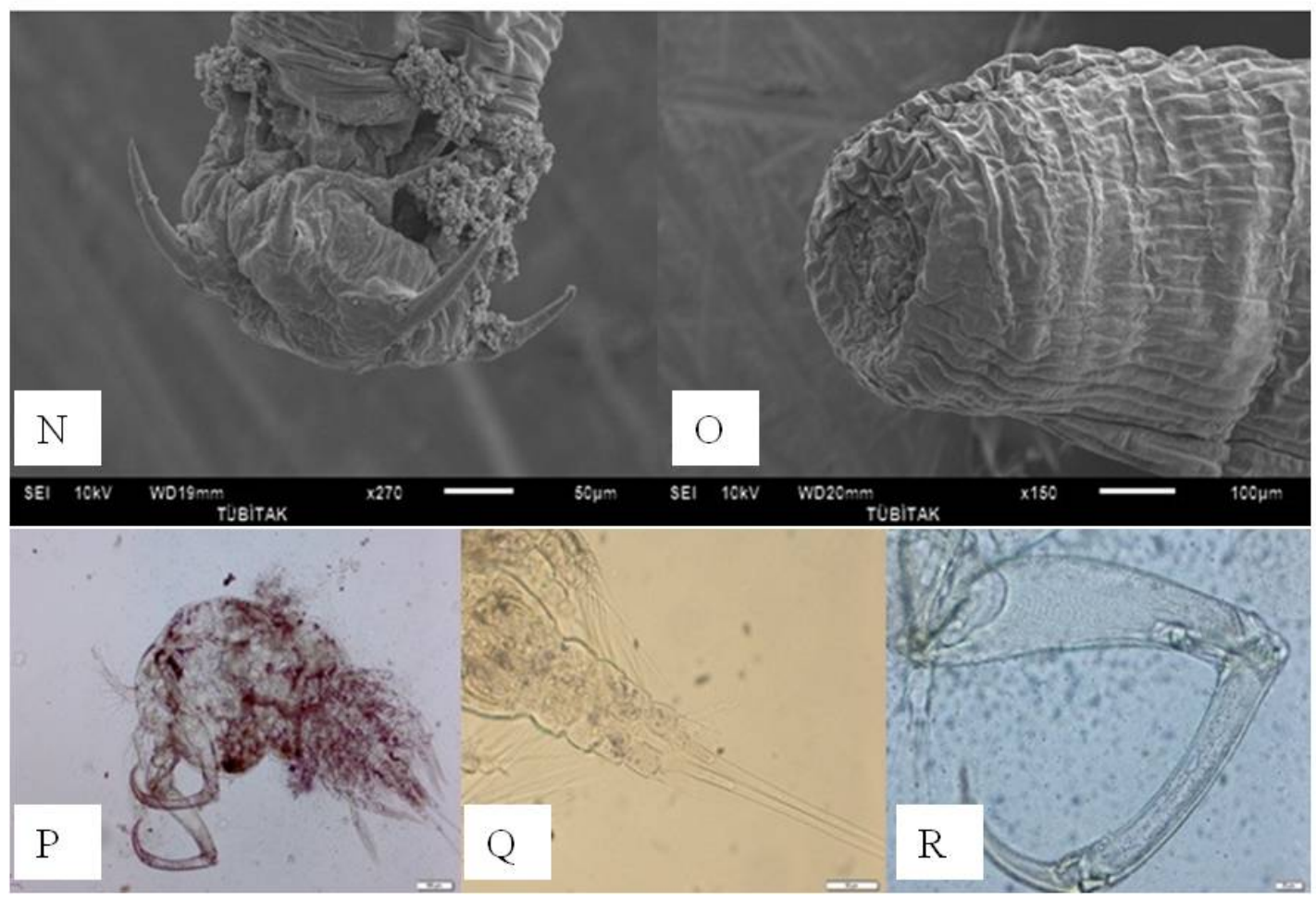

Plate I. - third part. L - Thylodelphys clavata; M, N, O - Neoechinorhychus agilis; P, Q, R - Ergasilus lizae Scale bars: $\mathrm{M}-500 \mu \mathrm{m} ; \mathrm{L}, \mathrm{O}, \mathrm{P}-100 \mu \mathrm{m} ; \mathrm{N}, \mathrm{Q}-50 \mu \mathrm{m} ; \mathrm{R}-20 \mu \mathrm{m}$

lids studied to date have been infected with more than 1 species of Ligophorus, it is natural to assume that this genus is far more diverse than currently described. Here in the present study, two species of Ligophorus and one species of Microcotyle were identified. Twelve species of Ligophorus are strictly specific to mugilids; including Ligophorus cephali and L. mediterraneus on Mugil ceph276 alus (Sarabeev et al., 2005; Dmitrieva et al., 2012). There are several reports of only Microcotyle mugilis parasitizing golden grey mullet, and there is no report on Ligophorus cephali and L. mediterraneus on this fish species at present (see Table 1). Here, in the present study, both species were found on Liza aurata for the first time. The known geographical and host range of $L$. mediterraneus has been 
expanded by Rubtsova et al. (2006) on M. cephalus in the Black and Azov Seas. Ligophorus cephali has also been reported to be specific to $M$. cephalus in different sampling areas (Rubtsova et al., 2006; Dmitrieva et al., 2009a,b; Dmitrieva et al., 2012). Both, Ligophorus cephali and L. mediterraneus are the first records for Turkish parasitic fauna in fish as well. Microcotyle mugilis, previously being reported in Turkey, was the other monogenean described in the present study and elsewhere (see Table 1). There is no record on the presence of digenean trematodes Ascocotyle (Phagicola) longa and Thylodelphys clavata in L. aurata and they are identified in this fish species for the first time in the present study, too. On the other hand, Haplosplanchnus pachysomus, Neoechinorhynchus agilis and Ergasilus lizae have been reported in L. aurata several times (see Table 1).

Studies on the trichodinids in Turkey have increased considerably in the recent years. Özer and Erdem (1998; 1999), Özer (2000; 2003a; 2003b; 2007), Öztürk and Özer (2008) conducted comprehensive studies on several trichodina species, namely $T$. acuta, T. mutabilis, T. nigra, $T$. domerguei, $T$. jadranica, T. modesta and T. tenuidens in different environments as well as host species. Trichodina puytoraci and $T$. lepsii have been studied only once and were reported for the first time by Özer and Öztürk (2004). Infection prevalence $(56.52 \%)$ and mean intensity value $(81.11 \pm 36.56)$ determined in the present study for Trichodina-group were quite higher than that of Özer and Öztürk (2004) who reported infection prevalence of $40.6 \%$ and mean intensity value of $5.46 \pm 1.07$ Trichodina puytoraci per infected fish in a small stream connected to the Black Sea in Sinop. It must be noted that T. lepsii was dominant species in the present study while $T$. puytoraci was only species in the above mentioned study. Environmental factors in different levels at both sampling sites might have affected in favour of one species than the other. Higher level of intensity value in Kiz1lirmak Delta might reflect the promoting potential of this sampling area for trichodinid infections. Yemmen et al. (2012) reported an infection prevalence value of $T$. lepsii from $L$. aurata as $6 \%$, only from saline Ghar El Mehl Lagoon in Tunisia. The infection prevalence was highest in brackish Kizılırmak Delta and lowest in saline Ghar El Mehl Lagoon in Tunisia, with that of a slightly brackish small stream in Sinop in between. These infection indices provided above show a clear effect of salinity on this parasite species.

Studies on monogenean parasites of Liza aurata are very limited (see Table 1) and only 7 parasite species reported from Mediterranean, Azov and Black Seas so far (Gaevskaya \& Dmitrieva 1997; Dmitrieva \& Gaevskaya 2001; Mariniello et al., 2004; Sarabeev \& Balbuena 2004; Merella \& Garippa 2001; Ragias et al., 2005; Dmitrieva et al., 2012). Here in the present study, we have identified Ligophorus cephali and $L$. mediterraneus in the gills of $L$. aurata for the first time making the sum of 9 monogenean species reported from this fish species where survive. These 2 species have so far been reported from their type host Mugil cephalus from the Mediterranean and Black Seas (Sarabeev et al., 2005; Rubtsova et al., 2006; Dmitrieva et al., 2009a,b). Sarabeev et al. (2005) identified Ligophorus mediterraneus as a new species and provided infection prevalence $(\%)$ and intensity ranges from different environments; $71 \%$ and $2-19$ worms per fish in Gulf of Valencia in the Mediterranean Sea: $24 \%$ and $6-24$ worms per fish in Kerch Channel in the Black Sea. $\mathrm{Li}$ gophorus cephali was identified as a new species by Rubtsova et al. (2006) with some data regarding to its infection values. Infection prevalence (\%) and intensity ranges for $L$. cephali were $100 \%, 7-91$ worms per fish in Gulf of Valencia; $56 \%, 1-22$ worms per fish in Ebro River Delta in the Mediterranean Sea; 58 \%, 1 - 69 worms per fish in Kerch Channel in the Black Sea. In the present study, we determined infection prevalence and mean intensity values for Ligophorus-group as $97.83 \%$ and $87.00 \pm 17.13$ worms per fish, respectively. It must be reminded that a rate of $75: 1$ in favour of $L$. cephali over L. mediterraneus was recorded in the present study. Thus, the above mentioned values mainly reflect the infection capability of $L$. cephali. It is obvious that the infection values determined here for $L$. cephali are close to those of reported for the same parasite species from M. cephalus in Gulf of Valencia in the Mediterranean Sea possibly reflecting its higher infection capability regardless of geographical and salinity differences where they were found. Our study also provides information about both parasite species being together on the same host and a possible competition in favour of $L$. cephali over $L$. mediterraneus. This possibility, however, warrants more studies on this subject.

Microcotyle mugilis was the other monogenean recorded from $L$. aurata in the present study with infection prevalence of $8.7 \%$ and mean intensity of $2.75 \pm 1.44$ worms per infected fish. Gaevskaya and Dmitrieva (1997) and Dmitrieva and Gaevskaya (2001) reported this parasite form L. aurata in the Black Sea without any infection parameters. However, El-Hafidi et al. (1998) provided very similar infection prevalence and mean intensity values (10.13\%, 2.06 worms per infected fish) for Microcotyle mugilis in Mugil cephalus in Morocco. Oğuz and Bray (2008) also reported very low level of infection values $(5.5 \%, 1 \pm 0$ worms per fish) in Liza ramada in Sea of Marmara in Turkey. The above mentioned infection values along with ours of this big monogenean species show that this parasite may survive in different habitats (Sea of Marmara, the Mediterranean and Black Seas) with different salinity and temperature with low level infection occurrences.

Digeneans are important fish parasites with fishes serving mainly intermediate hosts. Three species of digeneans, namely Ascocotyle (Phagicola) longa, Haplosplanchnus pachysomus and Tylodelphys clavata, were identified in $L$. aurata in the present study. Ascocotyle (Phagicola) longa is a widespread parasite recorded from the Americas, Europe, Africa and the Middle East in different fish species, however, there is no record in L. aurata so far. It is considered to be one of the causative agents of heterophyiasis, an 
emerging fish-borne disease of humans (Scholz et al., 2001). The adult parasites are found in the intestine of fisheating birds and mammals, and the metacercariae are found mainly in mullets (Mugil spp.). Tylodelphys clavata is a member of Diplostomidae which metacercarial stage parasitize the eye of fish. The economic significance of the eyediseases of cultured fish, is associated with specific effects or non-specific side effects of parasites, including impairment of vision that leads to exophthalmus, cataract and even complete collapse of the eye, which may be the cause of growth inhibition and death of significant portions of cultured fishes (Barzegar et al., 2008). Tylodelphys clavata has not been reported from L. aurata anywhere in the world so far, thus, this is the first report of this parasite species from this host fish. The genus Haplospanchnus is one of the well known parasites of Mugilidae and Haplosplanchus pachysomus causes limited pathology on hosts (Ragias, 2005). Haplosplanchnus pachysomus is the third digenean species found $L$. aurata in the present study and it has been reported from the Black and Azov Seas by Dmitrieva \& Gaevskaya (2001) and from Mediterranean Sea by Ragias et al. (2005). Infection prevalence (\%) and mean intensity values determined for Ascocotyle (Phagicola) longa and Tylodelphys clavata were very low when compared to Haplosplanchnus pachysomus (see table 2). As was mentioned above, Ascocotyle (Phagicola) longa and Tylodelphys clavata are the new parasite species for L. aurata and there is no comparable data for their infective occurrences. On the other hand, infection prevalence $(39.13 \%)$ determined in the present study for Haplosplanchnus pachysomus was higher than that of Ragias et al. (2005) who reported infection prevalence of $24.4 \%$ in the same fish species in Greece. It must be noted that the mean intensity value $(128.72 \pm 37.77)$ determined in $L$. aurata was the highest among all identified parasite species in the present study.

Acanthocephalans are 'thorny' or 'spiny headed' worms with aquatic life cycles; fish as final or paratenic hosts and crustaceans as intermediate hosts. Adults feed on the intestinal walls of vertebrates, especially freshwater and marine fishes, in general, they have a limited interest in fish pathology. Neoechinorhyncus agilis is the only species found in L. aurata with infection prevalence of $47.83 \%$ and mean intensity of $6.14 \pm 1.58$ worms per fish in the present study. This species was reported from L. aurata in the Mediterranean Sea by Merella and Garippa (2001) and Ragias et al. (2005) and in the Black and Azov Seas by Dmitrieva and Gaevskaya (2001). Our infection prevalence value was quite higher those of Ragias et al. (2005) (4.1\%) and Merella and Garippa (2001) (16\%).

Parasitic copepods are common on cultured and wild marine finfish, including mullets, and there is a vast literature describing their taxonomy and host ranges (see Johnson et al., 2004 for detailed host - parasite list). Many of these species have long been recognized to have the potential to affect the growth, fecundity and survival of wild hosts. Ergasilid copepods have been reported from a variety of finfish reared in brackish and marine waters. Outbreaks of disease caused by ergasilids are a major source of copepod-induced mortality in brackish water finfish culture. Ergasilus lizae is the only species found in L. aurata with infection prevalence of $50 \%$ and mean intensity of $6.87 \pm$ 1.72 parasites per fish in the present study. Heavy infections of Ergasilus lizae on the gills have been reported to cause gill damage, morbidity, and in most instances, substantial mortalities in grey mullet (Mugil cephalus) cultured in brackish water ponds. This parasite is known to be common on Mugil planatus but, there is only one paper on L. aurata reporting its life cycle without any infection parameters (Ben Hassein \& Raibaut, 1981).

Water parameters measured from Liman and Karaboğaz Lagoons in the lower Kizilirmak Delta were presented in Table 3 to give a brief understanding of parasite - environmental factors relationship and it is thought that especially direct life cycled parasite species have been affected somehow by those water parameters.

In conclusion, a total of 10 parasite species was identified, 6 being ecto- and 4 being endoparasites, in the present study. Trichodinid, monogenean and ergasilid parasites have a simple direct life cycle that is more dangerous than that of digenean and acanthocephalan parasites which have complex life cycle in causing sudden epidemics. Moreover, members of direct life cycled parasites identified had the highest infection prevalence that those of complex life cycled parasites in the present study. Monogeneans are typically external parasites of fishes including teleosts and elasmobranches and are considered among the most host specific parasites of all fish parasites Among three species of digenean parasites, one of them (Ascocotyle (Phagicola) longa) has a zoonotic character which pose a threat to human and the other (Tylodelphys clavata) has a potential to eye diseases of fish. Besides, mullets are the most commonly found wild fish in close contact with cultured fish, as they feed on cultured fish debris and are often caught inside the cages. Thus, the presence of these parasites in mullets shows parasite transmission to cultured fish and may reflect the problem of enlargement of the host range of parasitic species under artificial conditions.

\section{Acknowledgement}

This study was financially supported by Turkish Scientific and Technological Research Council (TÜBİTAK) with the Project Number 110O424. Authors are grateful to TÜBITAK for this support.

\section{References}

BArzegar, M., Raeisi M., Bozorgnia A., Jalali, B. (2008): Parasites of the eyes of fresh and brackish water fishes in Iran. Iran. J. Vet. Res., 9(3): 256-261

Ben Hassein, O. K., Raibaut, A. (1981): Experimental realization of the life cycle of Ergasilus lizae Kroyer, 1853, parasitic copepoda of the fish Mugilidae. First results of infestation. Arch. Inst. Pasteur Tunis, 58(3): $423-$ 430 
Bush, A. O., Lafferty, K. D., Lotz J. M., Shostak, A. W. (1997): Parasitology meets ecology on its own terms: Margolis et al. revisited. J. Parasitol., 83(4): 575 - 583

Chernova, T. N. (1967): To the studies of myxosporidia fauna in fish of some water reservoirs of the western Georgia. Trudy nauch.-issled. ribokhozyaystvennoy stantsii Gruzii. 12: 12 - 20 (In Russian)

Dmitrieva, E. V., Gaevskaya, A. V. (2001): Parasitological aspects of mugilids mariculture and of their introduction into the Sea of Azov and the Black Sea. Ecologiya Morya, 55: $73-78$

Dmitrieva, E. V., Gerasev, P. I., Merella, P., PugACHEV, O. N. (2009a): Redescription of Ligophorus mediterraneus Sarabeev, Balbuena \& Euzet, 2005 (Monogenea: Ancyrocephalidae) with some methodological notes. Syst. Parasitol., 73: 95 - 105. DOI: 10.1007/s11230009-9177-7

Dmitrieva, E. V., Gerasev, P. I., Merella, P., PugAcheV, O. N. (2009b). Redescription of Ligophorus cephali Rubtsova, Balbuena, Sarabeev, Blasco-Costa \& Euzet, 2006 and L. chabaudi Euzet \& Suriano, 1977 (Monogenea: Ancyrocephalidae), with notes on the functional morphology of the copulatory organ. Syst. Parasitol., 73: 175 - 191. DOI: 10.1007/s11230-009-9192-8

Dmitrieva, E. V., Gerasev P. I., Gibson D. I., Pronkina N. V., Galli P. (2012). Descriptions of eight new species of Ligophorus Euzet \& Suriano, 1977 (Monogenea: Ancyrocephalidae) from Red Sea mullets. Syst. Parasitol., 81: 203 - 237. DOI: 10.1007/s11230-011-9341-8

El-Hafidi, F., Berrada-RKhami O., BenazzoU T., GABRION C. (1998): Microhabitat distribution and coexistence of Microcotylidae (Monogenea) on the gills of the striped mullet Mugil cephalus: chance or competition? Parasitol. Res., 84: 315 - 320

GaEvsKayA, A. V., DMitrieva E. V. (1997): Overview of Black Sea monogenean fauna. Ecologiya Morya, 46: 7-17. Holzer, A. S., Blasco-Costa, I., Sarabeev, V. L., Ovcharenko, M. O., Balbuena, J. A. (2006): Kudoa trifolia sp. n. - molecular phylogeny suggests a new spore morphology and unusual tissue location for a well-known genus. J. Fish Dis., 29: 743 - 755. DOI: 10.1111/j.13652761.2006.00770.x

Johnson, S. C., Treasurer, J. W., Bravo, S., NagAsaWA, K., KabATA, Z. (2004): A review of the impact of parasitic copepods on marine aquaculture. Zool. Stud., 43(2): 229 - 243

Lubat, V., Radujkovic, B., Marques, A., Bouix, G. (1989): Parasites des poissons marins du Montenegro: Myxosporidies. Acta Adriat., 30: 31 - 50

Mariniello, L., Ortis, M., D’Amelio, S., Petrarca, V. (2004): Morphometric variability between and within species of Ligophorus Euzet \& Suriano, 1977 (Monogenea: Ancyrocephalidae) in the Mediterranean Sea. Syst. Parasitol., 57: 183 - 190. DOI: 10.1023/B:SYPA.0000019080. 43784.06

Merella, P., GaripPA, G. (2001): Metazoan parasites of grey mullets (Teleostea: Mugilidae) From The Mistras Lagoon (Sardina, western Mediterranean). Sci. Mar.,
65(3): $201-206$

NeLSON, J. S. (2006): Fishes of the world. 4th Edition. In: John Wiley and Sons, New York.

OĞUZ, M. C., BRAY, R. A. (2008): Cestoda and monogenea of some teleost fishes off the Mudanya coast (Sea of Marmara, Turkey). Helminthologia, 45(4): 192-195. DOI: 10.2478/s11687-008-0038-8

ÖZER, A. (2000): The occurrence of three species of Trichodina (Ciliophora: Peritrichia) on Cyprinus carpio in relation to culture conditions, seasonality and host characteristics. Acta Protozool., 39: $61-66$

ÖZER, A. (2003a): The occurrence of Trichodina domerguei Wallengren, 1897 and Trichodina tenuidens Faure-Fremiet, 1944 on three spined stickleback, Gasterosteus aculeatus L., 1758 found in a brackish and freshwater environment. Acta Protozool., 42: 41 - 46

ÖZER, A. (2003b). Trichodina domerguei Wallengren, 1897 (Ciliophora: Peritrichia) infestations on the round goby, Neogobius melanostomus Pallas, 1811 in relation to seasonality and host factors. Comp. Parasitol., 70(2): 132 - 135. DOI: $10.1654 / 4073$

ÖZER, A. (2007): Trichodina modesta Lom, 1970 (Ciliophora: Peritrichia) infestations of an endemic toothcarp Aphanius danfordii Boulenger, 1890 (Pisces: Cyprinodontidae) in Sinop, Turkey. J. Nat. Hist., 41: 2543 - 2549. DOI:10.1080/ 00222930701739724

ÖZER, A., ERDEM, O. (1998): Ectoparasitic protozoa fauna of the common carp (Cyprinus carpio L., 1758) caught in the Sinop region of Turkey. J. Nat. Hist., 32: $441-454$. DOI:10.1080/00222939800770231

ÖZER, A., ERDEM, O. (1999): The relationship between occurrence of ectoparasites, temperature and culture conditions; a comparison of farmed and wild common carp (Cyprinus carpio L., 1758) in the Sinop region of northern Turkey. J. Nat. Hist., 33: 483 - 491. DOI: 10.1080/002229399300209

ÖZER, A., ÖZTÜRK, T. (2004): Trichodina puytoraci Lom, 1962 and Trichodina lepsii Lom, 1962 (Peritrichida: Ciliophora) Infestations on Mugilids caught at the Black Sea coast of Sinop in Turkey. Turk. J. Zool., 28: $179-182$

ÖZTÜRK, T., ÖZER, A. (2008): Parasitic fauna of the flounder, Platichthyes flesus L., 1758 caught in the Sarıum Lagoon Lake in Sinop (Turkey) and the occurrence of parasites in relation to host factors. J. Fishscicom, 2(3): $403-418$

Perugia, A. (1891): Sulle Missosporidie dei Pesci marini. I. Bollettino Scientifico, 12: 34 - 39

PogoreltCeVA, T. P. (1964): Materials on investigations of parasitic Protozoa of Black Sea fishes. Problemy parazitologii. Trudy Ukrainskogo Obshchestva Parazitologov, 3: $16-29$

Ragias, V., Athanassopoulou, F., Sinis, A. (2005): Parasites of Mugilidae spp reared under semi-intensive and intensive conditions in Greece. Bull. Eur. Assoc. Fish Pathol., 25(3): $107-115$

Rubtsova, N. Y., Balbuena, J. A., Sarabeev, V. L., Blasco-Costa, I., Euzet, L. (2006): Description and morphometrical variability of a new species of Ligophorus 
and of Ligophorus chabaudi (Monogenea: Dactylogyridae) on Mugil cephalus (Teleostei) from the Mediterranean Basin. J. Parasitol., 92(3): 486 - 495. DOI: 10.1645/GE747R.1

SarabeeV, V. L., Balbuena, J. A. (2004): Ligophorus pilengas $\mathrm{n}$. sp. (Monogenea: Ancyrocephalidae) from the introduced so-iuy mullet, Mugil soiuy (Teleostei: Mugilidae), in the Sea of Azov and the Black Sea. J. Parasitol., 90(2): 222 - 228. DOI: 10.1645/GE-163R

SARABEeV, V. L., BAlbuenA, J. A., Euzet, L. (2005): Taxonomic status of Ligophorus mugilinus (Hargis, 1955) (Monogenea: Ancyrocephalidae), with a description of a new species of Ligophorus from Mugil cephalus (Teleostei: Mugilidae) in the Mediterranean basin. J. Parasitol., 91(6): 1444 - 1451. DOI: 10.1645/GE-418R.1

Scholz, T., Aguirre Macedo, M. L., SAlgado MALDONADO, G. (2001): Trematodes of the family Heterophyidae (Digenea) in Mexico: a review of species and new host and geographical records. J. Nat. Hist., 35(12): 1733 - 1772. DOI: 10.1080/ 00222930152667087

Sitja-Bobadilla, A., Alvarez-Pellitero, P. (1995) : Light and electron microscopic description of Polysporoplasma n. g. (Myxosporea: Bivalvulida), Polysporoplasma sparis n. sp. from Sparus aurata (L.), and Polysporo- plasma mugilis n. sp. from Liza aurata L. Eur. J. Protistol., 31: 77 - 89. DOI: 10.1016/S0932-4739(11)80360-3

URAWA, S. (1992): Trichodina truttae Mueller, 1937 (Ciliophora: Peritrichida) on juvenile chum salmon (Oncorhynchus keta): pathogenicity and host-parasite interactions. Gyobyo Kenkyu, 27(1): 29 - 37

Yemmen, C., Ktari, M. H., BAhri, S. (2012): Parasitofauna of some mugilid and soleid fish species from Tunisian lagoons. Acta Adriat., 52(1): 173 - 182

Yurakhno, V. M., OvcharenKo, M. O., Holzer, A. S., SARABEEV, V. L., BALBUENA, J. A. (2007): Kudoa unicapsula n. sp. (Myxosporea: Kudoidae) a parasite of the Mediterranean mullets Liza ramada and L. aurata (Teleostei: Mugilidae). Parasitol. Res., 101: 1671 - 1680. DOI: 10.1007/s00436-007-0711-8

Yurakhno, V. M., OvcharenKo, N. A. (2008): Myxosporeans of the World Ocean mullets. In GALAKTIONOV, K. V. AND DoBrovolsky, A. A. (Eds) Materialy IV Vserossiyskogo Syezda Parasitologicheskogo Obschestva pri Rossiyskoy Academii nauk, sostoyavshegosya 20 - 25 October 2008 v Zoologicheskom institute Rossiyskoy Academii nauk v Sankt-Peterburge: "Parasitologiya v XXI veke - problemy, metody, resheniya”. - Volume 3. St-Petersburg: "Lema", pp. $231-234$ 